\title{
Economic Effectiveness of Direct Drill in Maize Production
}

\author{
Desanka Žuža · Todor Marković*
}

University of Novi Sad, Faculty of Agriculture, Trg Dositeja Obradovića 8, 21000 Novi Sad, Serbia

\begin{abstract}
Summary: Within the concept of sustainable agriculture, raising environmental awareness of farmers and the preservation of natural resources, the implementation of the so-called conservation tillage began during the 1960s in the USA. It involves the application of a reduced or completely eliminated (no-till, zero tillage, direct drill) sowing tillage, which prevents soil erosion, improves soil quality and biodiversity, also significantly reducing gas emissions by implementing a set of technical solutions. The application of this concept requires the existence of appropriate machinery that enables the use of direct seeding on land where plant residues of previous crops are present in the amount of minimum $30 \%$. In addition to significant environmental impacts, this concept provides positive economic effects: for the whole society by eliminating the cost caused by soil degradation, but also for individual agricultural producers through the elimination of a significant number of complex machining operations and savings in diesel fuel and working hours of machines and employees. A comparative analysis of the economic effectiveness of maize production in terms of conventional tillage and no-till on a farm in Novi Sad showed that the application of direct drill allows skipping 4 to 5 machining operations, leading to a saving of 59 litres of diesel fuel per hectare of cultivated area while retaining the same average yield per ha, which resulted in increased profits by 4,246 RSD ha-1 compared to conventional tillage.

Key words: agricultural economics, cost-effectiveness, drilling, economic analysis, maize, zero tillage
\end{abstract}

\section{Introduction}

Conservation agriculture (CA) is defined in the context of the system of sustainable agricultural development, which includes agricultural practices adapted to the requirements of crops and local conditions, including tillage and land management techniques that ensure the protection of soil against erosion and degradation, improve its quality and allow biodiversity and conservation of natural resources, water and air, with yield optimization ("What is conservation agriculture?", 2015).

Agricultural practices applied within the CA concept are based on three main principles:

1. Minimum soil disturbance

2. Maintenance of permanent soil cover

3. Cropping system diversity, crop rotations ("What is conservation agriculture?", 2015).

Corresponding author:

todor.markovic@polj.edu.rs

Acknowledgement:

This study is part of the project III46006 titled "Sustainable agriculture and rural development in order to achieve strategic goals Republic of Serbia in the Danube region" and the project TR31011 titled "Effect of components quality in cyprinids feeding on meat quality, losses and economic efficiency" subsidized by the Ministry of Education, Science and Technological Development of the Republic of Serbia.
CA concept includes many reduced tillage systems, with direct drill as the extreme form of reduced tillage (no-till, zero tillage, direct drill), which includes the complete omission of mechanical sowing tillage and direct seeding into the soil covered with plant remains of a culture cultivated in the previous season. CA concept, in North and South America, as well as in Australia with New Zealand, mostly means the use of direct seeding, while in Europe more lenient forms of reduced tillage are used, which are also subsumed under the concept of CA (Schmitz et al., 2015).

Ecological importance of this concept is reflected in preventing soil erosion and reducing emissions. It is estimated that 115 million ha of agricultural land (12\%) in Europe are threatened by the influence of soil erosion. It leads to the degradation of land, which in extreme cases can lead to the complete inadequacy of land for the cultivation of plants (Schmitz et al., 2015). Application of reduced tillage reduces the emission of $\mathrm{CO}_{2}$ per ha to $1.8 \mathrm{t}$ per year (FAO, 2008). On 5 billion ha of agricultural land, this could represent $1 / 3$ of current $\mathrm{CO}_{2}$ emissions per year originating from the combustion of fossil fuels in the world.

The first ideas about the possibility of applying this concept, originated in 1940s, when Edward Faulkner questioned the necessity of conventional tillage as form of sowing preparations in his book "Plowman's 
Folly" (1943). However, the use of direct drill until 1980 s was very rare. During this period, most of studies in this field were completed by Ohio University (USA) in cooperation with local farmers. However, significant use of direct drill has occurred since 2000. The reasons for this delay were found in the undeveloped specific machinery that would have allowed direct sowing, but also in prices of herbicides, which until 2000 were high, as Monsanto's patent for glyphosate expired that year. Also in this period, the price of diesel fuel started to rapidly increase (Islam and Reeder, 2014; Reicosky and Hanson, 2007; Epplin, 2007).

Today, CA in the world is applied to over 125 million ha, or about $10 \%$ of arable land, while in Europe this area is 22.7 million hectares, or $25.8 \%$ of arable land. European countries, with the largest share of land with applied reduced tillage in total arable land are: Cyprus (62.1\%), Bulgaria (58.0\%), Germany (41.1\%), United Kingdom (39.2\%), Finland (38.7\%), France and Switzerland (36.4\%), Czech Republic (34.8\%) and Luxembourg with $31.0 \%$ of arable land (Madarász and Kertesz, 2014).

In recent years, significant efforts have been invested in the development of an institutional framework for the regulation of the system of cultivation and conservation of natural resources in the European Union (EU). Development of "EU Soil Thematic Strategy" was supposed to facilitate the development and implementation of integrated policies of the EU in the field of preservation of soil as a natural resource. However, the Directive of the European Commission, which was supposed to enable the legal framework for this strategy, was rejected in May 2014 by the European Parliament. The United Kingdom, Germany, Austria, France, and the Netherlands voted against this Directive, as they considered that this area should be governed by local communities. However, the promotion and dissemination of the CA concept is supported by numerous organizations, amongst which the most important are: European Conservation Agriculture Federation (ECAF) in Europe, and Food and Agriculture Organization of United Nations (FAO) in the world, through the "Global Soil Partnership" ("The European Parliament tackles the benefits of Conservation agriculture in the seminar "Making Sustainable Agriculture Real", 2016; FAO, 2015).

Economic effects of CA and reduced tillage can be seen from the general, social perspective and from the perspective of the individual producer. From the standpoint of the entire community, the positive effects are manifested through the prevention of soil erosion and $\mathrm{CO}_{2}$ emissions. According to estimates of ECAF, the cost of the damage that occurs as a result of soil erosion is about $32 \mathrm{EUR} \mathrm{ha}^{-1}$. This figure includes costs that are caused by damage generated by soil erosion, such as pollution of water, damage to roads, sewers, canals, the cost of water treatment, as well as floods.
Individual farmers, using reduced tillage, in addition to the savings that can provide for the entire community, may also provide significant direct cost savings, which are manifested through savings in the cost of diesel fuel and working hours of machines and people.

During experiments with direct drilling in Ohio, retaining and in some cases increase of yields was noticed, compared to conventional tillage (Islam and Reeder, 2014). In Europe, during experiments in Hungary, yield increase of $10 \%$ was found, with the emergence of a lower decrease in yields in the first year of application of the concept of reduced tillage. On the other hand, in Ukraine, on chernozem, yield increased from $5 \%$ to $10 \%$, while the largest yield increase was observed in Southern Europe (Portugal and Spain) from $10 \%$ to $15 \%$, especially in the dry season (Kertesz and Madarász, 2014). Examples of lower yields achieved in terms of reduced tillage compared to conventional tillage were found in the countries of Northern Europe: Sweden, Denmark and Norway. In these countries, decline in yields ranged from $5 \%$ to $12 \%$, with the extreme values recorded in Finland, on the clayey soil (a decrease of $20 \%$ to $40 \%$ ). On the other hand, the highest increase in yield, in the reduced tillage, was recorded by the countries of southern Europe: Portugal and Spain (from 3\% to 13\%), while the highest growth was recorded in the arid region of northern Spain, where yields were doubled (Soane et al., 2012). Due to the research above, the economic effects of reduced tillage, for individual producers, could be viewed from the aspect of revenue, if its application leads to yield changes, compared with the yield achieved in terms of conventional tillage.

The aim of this study was to determine the economic effectiveness of applying the concept of reduced tillage compared to the previous, conventional tillage system, by comparing the results achieved using both concepts in the case of maize production.

\section{Materials and Methods}

Analysis was performed on the farm from the wider territory of Novi Sad, which applied both concepts of tillage, in the case of maize production. This farm applies direct drill on individual plots since 2009. In the observed season of $2013 / 2014$ corn was sown by direct seeding on 93.33 ha, while conventional seeding included 334.88 ha. Direct drill was completed with special 12-rows planter that allows direct sowing into the soil covered with crop residues from the previous season, while conventional sowing was performed by classic pneumatic planter for corn. Both seeders allow direct application of fertilizer at sowing.

In order to complete necessary calculations, this report used prices and usage data of the raw materials. For the prices of raw materials and finished products (corn), the average prices that the farm realized on the 
market during the season 2013/2014 were taken. Information on usage of raw materials and performed machining operations originated from the records maintained by the farm and relate to the season 2013/2014. Determination of the economic effectiveness of application of reduced tillage for individual farmers was made through the comparative analysis of the results in terms of conventional tillage and the results that were achieved using the direct seeding. Calculation of production was carried out for both concepts and includes: calculation of costs and revenues from the production of corn observed in terms of both concepts, calculation of results of production for both concepts and determining its difference. Cost analysis includes: costing of the base material, auxiliary materials and the cost of driving machines, while the fixed costs are included in the category of other expenses, and are not analytically construed, as it does not affect the results of the comparative analysis (changing production concept does not affect these costs). The cost of the basic material involves the cost of seeds and fertilizers; the cost of auxiliary materials is related to the cost of pesticides used, while the cost of power machines relates to the calculation of the cost of diesel fuel, which originate from execution of the necessary mechanical operations. Also, sensitivity analysis was performed measuring effects of change of three parameters: yield and prices of fuel and pesticides.

\section{Results and Discussion}

During analysis of the variable costs of maize production the following are discussed: the costs of basic materials, auxiliary materials costs, and the costs of driving machines.

The cost of the basic material includes the costs of seeds and fertilizers. Calculating average cost per hectare, for both concepts, it was found that the cost of the base material does not depend on changes in the concept of production, and in both cases the amount was the same (Table 1). On the other hand, cost of auxiliary materials, which includes the calculation of the costs of pesticides, points to some differences that exist between the two tillage systems (Table 2).

Table1. Cost of basic material in terms on direct drill and conventional tillage

\begin{tabular}{lccc}
\hline Material & $\begin{array}{c}\text { Base unit of } \\
\text { measure }\end{array}$ & $\begin{array}{c}\text { Usage } \\
\text { per ha }\end{array}$ & $\begin{array}{c}\text { Average cost } \\
\text { per ha (RSD) }\end{array}$ \\
\hline Seeds & Seed unit & 2.80 & 14,791 \\
Fertilizer & $\mathrm{kg}$ & 600 & 24,201 \\
\hline Total: & & & 38,991 \\
\hline
\end{tabular}

Table 2. Cost of auxiliary materials in terms of direct drill

\begin{tabular}{lccc}
\hline Material & $\begin{array}{c}\text { Base unit } \\
\text { of measure }\end{array}$ & $\begin{array}{c}\text { Usage per } \\
\text { ha }\end{array}$ & $\begin{array}{c}\text { Average cost } \\
\text { per ha (RSD) }\end{array}$ \\
\hline Herbicides & 1 & 8.50 & 6,071 \\
Surfactants & 1 & 0.20 & 162 \\
Insecticides & 1 & 0.20 & 7,000 \\
\hline Total: & & 8.90 & 13,233 \\
\hline
\end{tabular}

Table 3. Cost of auxiliary materials in terms of conventional tillage

\begin{tabular}{lccc}
\hline Material & $\begin{array}{c}\text { Base unit } \\
\text { of measure }\end{array}$ & $\begin{array}{c}\text { Usage per } \\
\text { ha }\end{array}$ & $\begin{array}{c}\text { Average cost } \\
\text { per ha (RSD) }\end{array}$ \\
\hline Herbicides & 1 & 6.95 & 3,680 \\
Surfactants & 1 & 0.20 & 162 \\
Insecticides & 1 & 0.20 & 7,000 \\
\hline Total: & & 7.35 & 10,841 \\
\hline
\end{tabular}

We can notice that the herbicides were applied in higher rate in terms of direct drill than in the case of conventional tillage. In particular, reduced tillage required the consumption of $1.551 \mathrm{ha}^{-1}$ of herbicide more, which caused a higher cost of pesticides in the amount of 2,392 RSD ha-1. In percentages, the treatment of herbicides was $21.09 \%$ higher, and the cost of pesticides is $22.06 \%$ higher in terms of reduced tillage.

A comparative analysis of the costs of driving machines includes the calculation of the cost of diesel fuel that occurs while performing the machining operations, observed separately, for both concepts.

Based on Tables 4 and 5, it can be noticed that the application of direct drill allowed skipping 4 machining operations of pre-sowing soil preparation: mulching, ploughing and two preparations, as well as inter row cultivation because it also performs soil disturbance. In this way, a consumption of diesel fuel per ha was lower by 59 , which resulted in savings of $6,377 \mathrm{RSD}^{\mathrm{h}}{ }^{-1}$.

After the harvest, in the context of observing the overall results of both concepts of production, the average maize yield per hectare was measured for both concepts. The average yield was achieved in about the same amount in both terms. In the context of reduced tillage, yield per ha was about $11,250 \mathrm{~kg} \mathrm{ha}^{-1}$, while conventional production gave a slightly lower average yield of about $11,230 \mathrm{~kg} \mathrm{ha}^{-1}$.

Calculations were made for both concepts, in order to carry out comparative analysis at the level of the final results achieved and enable determining the economic effectiveness of performing reduced tillage. 
Table 4. Cost of diesel fuel in terms of direct drill

\begin{tabular}{lcccc}
\hline Machining operation & $\begin{array}{c}\text { Base unit of } \\
\text { measure }\end{array}$ & $\begin{array}{c}\text { Usage } \\
\text { per ha }\end{array}$ & $\begin{array}{c}\text { Area } \\
\text { (ha) }\end{array}$ & $\begin{array}{c}\text { Cost per ha } \\
\text { (RSD) }\end{array}$ \\
\hline Sowing & 1 & 11 & 93.33 & 1,287 \\
Seeds transportation & 1 & 2 & 93.33 & 234 \\
Fertilizers transportation $(3 \times)$ & 1 & 6 & 93.33 & 702 \\
Loading of fertilizers & 1 & 6 & 93.33 & 468 \\
Fertilizers broadcast $(2 \times)$ & 1 & 4 & 93.33 & 702 \\
Water transportation $(2 \times)$ & 1 & 6 & 93.33 & 468 \\
Spraying $(2 \times)$ & 1 & 28 & 93.33 & 702 \\
Harvesting & 1 & 63.33 & 3,276 \\
Maize transportation & 1 & 73 & 93.33 & 702 \\
\hline Total: & & 6,541 \\
\hline
\end{tabular}

Table 5. Cost of diesel fuel in terms of conventional tillage

\begin{tabular}{|c|c|c|c|c|c|}
\hline Machining operation & $\begin{array}{c}\text { Base unit of } \\
\text { measure }\end{array}$ & $\begin{array}{l}\text { Usage } \\
\text { per ha }\end{array}$ & $\begin{array}{c}\text { Cost } \\
\text { per ha (RSD) }\end{array}$ & $\begin{array}{c}\text { Area } \\
\text { (ha) }\end{array}$ & $\begin{array}{c}\text { Average } \\
\text { cost per ha } \\
\text { (RSD) }\end{array}$ \\
\hline Mulching of plant residues & 1 & 8 & 936 & 146.58 & 410 \\
\hline Ploughing & 1 & 24 & 2,808 & 334.88 & 2,808 \\
\hline Preparation $(2 \times)$ & 1 & 22 & 2,574 & 334.88 & 2,574 \\
\hline Sowing & 1 & 11 & 1,287 & 334.88 & 1,287 \\
\hline Seeds transportation & 1 & 2 & 234 & 334.88 & 234 \\
\hline Fertilizers transportation $(3 \times)$ & 1 & 6 & 702 & 334.88 & 702 \\
\hline Loading of fertilizers & 1 & 4 & 468 & 334.88 & 468 \\
\hline Fertilizers broadcast $(2 \times)$ & 1 & 6 & 702 & 334.88 & 702 \\
\hline Water transportation $(2 \times)$ & 1 & 4 & 468 & 334.88 & 468 \\
\hline Spraying $(2 \times)$ & 1 & 6 & 702 & 334.88 & 702 \\
\hline Harvesting & 1 & 28 & 3,276 & 334.88 & 3,276 \\
\hline Maize transportation & 1 & 6 & 702 & 334.88 & 702 \\
\hline Inter row cultivation & 1 & 5 & 585 & 334.88 & 585 \\
\hline Total: & & 132 & & & 14,918 \\
\hline
\end{tabular}


Table 6. Calculation of maize production in terms of direct drill

\begin{tabular}{llcc}
\hline No. & Description & $\begin{array}{c}\text { Base unit } \\
\text { of measure }\end{array}$ & $\begin{array}{c}\text { Amount } \\
\text { per ha }\end{array}$ \\
\hline 1. & Cost of basic material & RSD & 38,991 \\
2. & Cost of auxiliary material & RSD & 13,233 \\
3. & Cost of driving machines & RSD & 8,541 \\
4. & Other costs & RSD & 66,036 \\
\hline A. & Total costs & RSD & 126,800 \\
\hline 1. & Maize sales revenue & RSD & 146,250 \\
\hline B. & Total revenue & RSD & 146,250 \\
C. & Result (B-A) & RSD & 19,450 \\
\hline
\end{tabular}

Calculations of maize production in terms of direct drill and conventional tillage (Tables 6 and 7), showed that direct seeding obtained higher profits for individual producer for $4,246 \mathrm{RSD}^{-1}$, i.e. $27.93 \%$. This result is provided through savings in the cost of diesel fuel that exceed the cost of increased herbicide usage.

Prices of planters that are capable of performing direct drill are usually higher than prices of regular planters. For example, price of pneumatic 12-rows planter is about 18,000 to 28,000 EUR (excluding VAT) depending on additional equipment, while 12-rows planter, that allows direct drill, costs 38,000 to 48,000 EUR (excluding VAT) also depending on additional equipment. The prices of planters were collected from local dealers of agricultural machinery (territory of Novi Sad). Approximately, price difference between these two planters was 20,000 EUR. Assuming that the observed producer, in each season, would make the same amount of savings by direct drill $\left(4,246 \mathrm{RSD} \mathrm{ha}^{-1}\right)$, and that he is going to grow maize using direct drill on all 428.21 ha of maize, in 1 year and 5 months investment difference (20,000 EUR) could be compensated.

In order to determine the risks and opportunities that are followed by application of the concept of direct drill, compared with the current system of land cultivation, sensitivity analysis of the results, that are calculated in both versions, was carried out. Analysis includes changing three parameters: the yield per hectare
Table 7. Calculation of maize production in terms of conventional tillage

\begin{tabular}{llcc}
\hline No. & Description & $\begin{array}{c}\text { Base unit } \\
\text { of measure }\end{array}$ & $\begin{array}{c}\text { Amount } \\
\text { per ha }\end{array}$ \\
\hline 1. & Cost of basic material & RSD & 38,991 \\
2. & Cost of auxiliary material & RSD & 10,841 \\
3. & Cost of driving machines & RSD & 14,918 \\
4. & Other costs & RSD & 66,036 \\
\hline A. & Total costs & RSD & 130,786 \\
\hline 1. & Maize sales revenue & RSD & 145,990 \\
\hline B. & Total revenue & RSD & 145,990 \\
C. & Result (B-A) & RSD & 15,204 \\
\hline
\end{tabular}

in direct drill, the price of diesel fuel and the price of pesticides.

Performed sensitivity analysis indicates that change of achieved yield had significant impact on results in direct drill. Table 8 shows that every change of realized yield for $2 \%$, or $225 \mathrm{~kg} \mathrm{ha}^{-1}$, led to change of result difference of 2,945 RSD ha-1. Accordingly, in the observed case, the yield in a reduced tillage could fall by a maximum of $2.88 \%\left(324 \mathrm{~kg} \mathrm{ha}^{-1}\right)$, or to the level of $10,926 \mathrm{~kg} \mathrm{ha}^{-1}$, so that this concept remains more costeffective than a conventional tillage system.

Analysis of the impact of changes in the price of diesel fuel refers to the greater profitability of the concept of reduced tillage in terms of diesel prices increase. In particular, any increase of the price of diesel fuel by $2 \%\left(2.34 \mathrm{RSD} \mathrm{l}^{-1}\right)$ leads to the increase of result difference for $128 \mathrm{RSD} \mathrm{ha}^{-1}$ in favour of direct drill. The price of diesel fuel, which could cause conventional tillage to be more profitable than direct drill, must be below 39 RSD per litre.

The impact of changes in prices of pesticides had the lowest importance. Namely, every change in the price of pesticides of $2 \%$ changes the result by 68 RSD $\mathrm{ha}^{-1}$. Increase of price of pesticides has a negative impact on results in direct drill. If the increase in the price of pesticides exceeds $125 \%$, the concept of direct drill becomes less cost-effective compared to conventional tillage.

Table 8. Payback period calculation

\begin{tabular}{lcccccc}
\hline Year: & 0 & 1 & 2 & 3 & 4 & 5 \\
\hline Net period cash flow (EUR) & $-20,000$ & 14,748 & 14,748 & 14,748 & 14,748 & 14,748 \\
Discount factor & 1 & 0.97 & 0.94 & 0.92 & 0.89 & 0.86 \\
Discounted cash flow (EUR) & $-20,000$ & 14,318 & 13,901 & 13,496 & 13,103 & 12,722 \\
\hline
\end{tabular}

The discount rate used in this calculation is $3 \%$. This percentage has been chosen because it represents current interest rate for loans subsidized by Serbian Ministry of Agriculture. Retrieved from: http://www.mpzzs.gov.rs/jeftiniji-krediti-za-poljoprivrednike-kamata-3-odsto/ 
Table 9. Sensitivity analysis

\begin{tabular}{|c|c|c|c|c|c|c|c|c|c|c|c|c|c|}
\hline 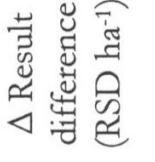 & 0 & $\begin{array}{l}\text { N̦ } \\
\stackrel{0}{+} \\
+1\end{array}$ & 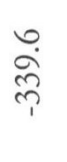 & $\begin{array}{l}\stackrel{\infty}{\circ} \\
\underset{\hat{T}}{\hat{i}}\end{array}$ & 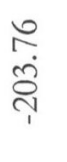 & 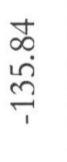 & $\frac{\widetilde{\alpha}}{\hat{\sigma}}$ & $\frac{\hat{\sigma}}{\hat{\sigma}}$ & 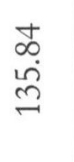 & 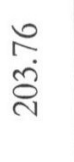 & 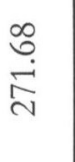 & $\begin{array}{l}\ddot{m} \\
\ddot{m}\end{array}$ & 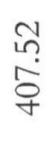 \\
\hline 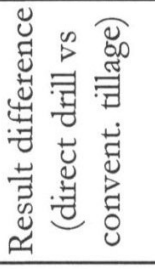 & 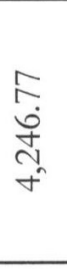 & $\begin{array}{l}\stackrel{2}{n} \\
\stackrel{2}{m} \\
\infty \\
\infty \\
\text { ñ }\end{array}$ & 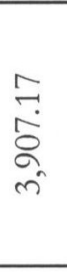 & $\begin{array}{l}\text { oे } \\
\text { in } \\
\hat{\sigma} \\
\text { nे }\end{array}$ & $\begin{array}{l}\overrightarrow{0} \\
\ddot{f} \\
\dot{\sigma} \\
\dot{f}\end{array}$ & 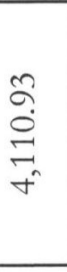 & 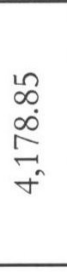 & \begin{tabular}{l}
$\hat{\sigma}$ \\
$\dot{+}$ \\
के \\
\multirow{+}{*}{}
\end{tabular} & \begin{tabular}{l}
$\vec{j}$ \\
in \\
$\infty$ \\
ॠn \\
\multirow{+}{*}{}
\end{tabular} & 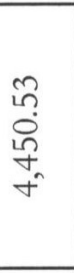 & 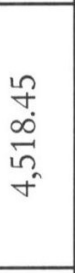 & 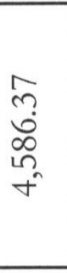 & 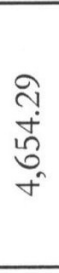 \\
\hline 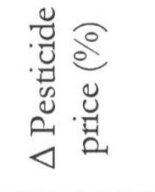 & 0 & $\stackrel{\sim}{\sim}$ & $\stackrel{ }{-}$ & $\infty$ & 0 & $\forall$ & $N$ & $\uparrow$ & 广 & i & $\infty_{i}$ & $\stackrel{ }{\underset{1}{1}}$ & $\stackrel{7}{7}$ \\
\hline 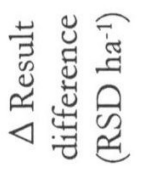 & 0 & ํํㅁ & $\begin{array}{l}\hat{\sigma} \\
\hat{\sigma} \\
\widehat{\sigma}\end{array}$ & $\underset{n}{\stackrel{0}{0}}$ & $\begin{array}{l}0 \\
\text { i } \\
\text { m } \\
n\end{array}$ & 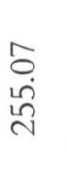 & 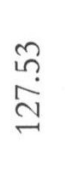 & 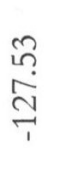 & 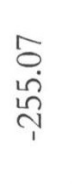 & $\begin{array}{l}0 \\
\text { ci } \\
\text { mo } \\
\text { r. }\end{array}$ & $\begin{array}{l}\stackrel{m}{0} \\
\stackrel{0}{i}\end{array}$ & $\begin{array}{l}\hat{\sigma} \\
\hat{\pi} \\
\hat{\psi}\end{array}$ & 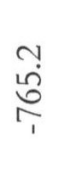 \\
\hline 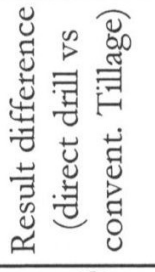 & \begin{tabular}{l}
$\hat{R}$ \\
$\dot{b}$ \\
\multirow{+}{*}{} \\
\multirow{\sigma}{*}{}
\end{tabular} & $\begin{array}{l}\hat{a} \\
\stackrel{a}{\sigma} \\
\text { in }\end{array}$ & 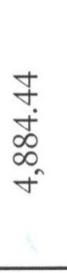 & $\begin{array}{l}\vec{\sigma} \\
\vec{b} \\
\stackrel{\circ}{\sigma} \\
\stackrel{f}{*}\end{array}$ & $\begin{array}{l}\hat{\text { }} \\
\text { ते } \\
\text { +े }\end{array}$ & 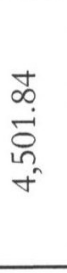 & 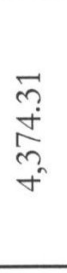 & 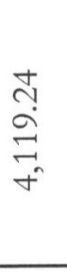 & $\begin{array}{l}\stackrel{2}{i} \\
\text { मू. } \\
\text { mे }\end{array}$ & 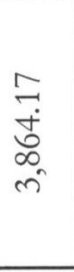 & $\begin{array}{l}\mathbb{J} \\
\stackrel{0}{0} \\
m \\
m\end{array}$ & $\begin{array}{l}0 \\
\stackrel{-}{0} \\
\text { Oे } \\
\text { r }\end{array}$ & in \\
\hline 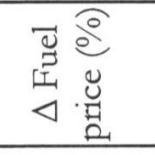 & 0 & $\stackrel{\sim}{\sim}$ & $\stackrel{ }{\circ}$ & $\infty$ & 0 & $\forall$ & $\sim$ & $\Upsilon_{1}$ & $\dot{T}_{1}$ & i & $\infty_{1}$ & $\stackrel{ }{\rightarrow}$ & $\stackrel{?}{7}$ \\
\hline 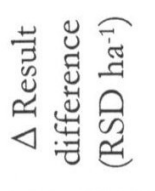 & $\stackrel{8}{\circ}$ & 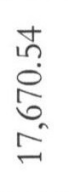 & 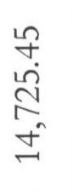 & $\begin{array}{l}\stackrel{\infty}{2} \\
\stackrel{\infty}{\infty} \\
\stackrel{-}{=}\end{array}$ & $\begin{array}{l}\hat{N} \\
\text { in } \\
\infty \\
\infty \\
\infty\end{array}$ & $\begin{array}{l}\infty \\
\stackrel{\infty}{\varnothing} \\
\infty \\
\infty \\
\text { in }\end{array}$ & $\begin{array}{l}g \\
0 \\
\dot{n} \\
\dot{a} \\
\hat{i}\end{array}$ & $\begin{array}{l}\text { oे } \\
\dot{+} \\
\text { के } \\
\text { î }\end{array}$ & $\begin{array}{l}\infty \\
\stackrel{2}{\circ} \\
\infty \\
\text { in } \\
\text { în }\end{array}$ & $\begin{array}{l}\hat{N} \\
\stackrel{1}{n} \\
\infty \\
\infty \\
\text { ô }\end{array}$ & 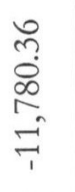 & 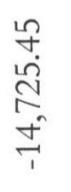 & 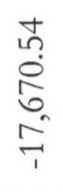 \\
\hline 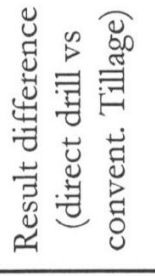 & 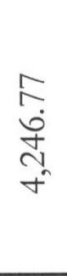 & $\begin{array}{l}\vec{n} \\
\overrightarrow{\vec{n}} \\
\vec{n}\end{array}$ & 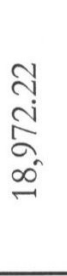 & 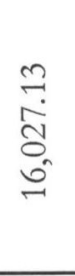 & $\begin{array}{l}\text { J } \\
\text { id } \\
0 \\
0 \\
2\end{array}$ & 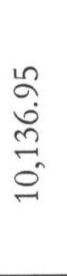 & 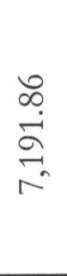 & 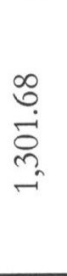 & $\begin{array}{l}\overrightarrow{+} \\
\stackrel{\text { qे }}{\mathrm{G}} \\
\vec{i}\end{array}$ & 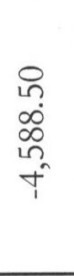 & 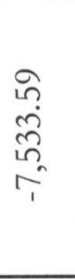 & 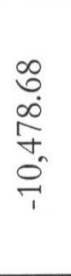 & 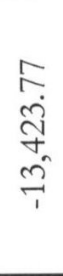 \\
\hline 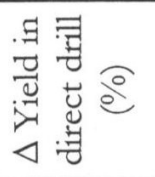 & 0 & $\stackrel{\sim}{\sim}$ & $\stackrel{-}{ }$ & $\infty$ & 0 & + & $N$ & $\mathcal{Y}$ & $\dot{T}_{1}$ & $\varphi_{i}$ & $\infty_{1}$ & $\stackrel{ }{\rightarrow}$ & $\stackrel{\mathfrak{T}}{\rightarrow}$ \\
\hline
\end{tabular}




\section{Conclusion}

In the spirit of growing awareness of the importance of soil, as a natural resource, the year 2015 was declared the "International year of soils" by the FAO, and 5 December was declared the "World soil day". These efforts of the United Nations, along with decade of attempts of EU to provide the legal framework for conscientious use of agricultural land beside promoting the $\mathrm{CA}$, represent a hint of future work on the application of modern methods of land management that rely on the concept of sustainable development and prevent soil erosion, among which the concept of reduced tillage certainly is. To the expansion of this concept, in addition to obligational legal norms that we can expect in the future, also contribute the economic motives, which are reflected in cost reductions that farmers can achieve. In this study, realized profit in terms of reduced tillage was higher by 4,246 RSD ha-1 than the profit made by using conventional tillage, i.e. $27.93 \%$. Lower fuel usage for 59 litres per ha, in the conditions of constantly increasing prices of diesel fuel, is one of the key economic motives for the implementation of this concept. On the other hand, one should not ignore the significant sensitivity of the results achieved using reduced tillage system, on the yield changes. In fact, any change in realized yields of $2 \%$ leads to the change of the profit for $15.14 \%$. This risk must be observed carefully, especially due to results of the research of some authors that noticed the decline in yields in the first years of application of this concept.

\section{References}

An Van den Putte, Govers, G., Diels, J., Gillijns, K., \& Demuzere, M. (2010). Assessing the effect of soil tillage on crop growth. A meta-regression analysis on European crop yields under conservation agriculture. Euroean Joumal of Agronomy, 33, 231-241.

Bajwa, A. A. (2014). Sustainable weed management in conservation agriculture. Crop Protection, 65, 105-113.

Chauhan, B. S., Singh, R. G., \& Mahajan, G. (2012). Ecology and management of weeds under conservation agriculture. Crop Protection, $38,57-65$.

FAO and Conservation technology information system (2008). Conservation Agriculture Carbon Offset Consultation. Beck agricultural center.
Godsey, C., Scott, G., Ford, J., Smolen, M., Taylor, R., Schrock, M., Wolf, R., Epplin, F., Zhang, H., Medlin, C., Hunger, R., Damicone, J., Royer, T., Edwards, J., Banks, J.C., \& Kochenower R. (2007). No-till cropping systems in Oklahoma. Oklahoma State University, Division of Agricultural Sciences and Natural Resources.

Islam, R., \& Reeder, R. (2014). No-till and conservation agriculture in the United States. An example from the David Brandt farm, Carroll, Ohio. International Soil and W ater Conservation Researh, 2, 97-107.

Janssen, L., \& Harer, J. (2010). An Economic Analysis of No-Till Rotations and Effects on Carbon Sequestration and Long Term Sustainability of Agriculture. Department of Economics, South Dakota State University, presented at AAE A 2010 Joint Annual Meeting.

Karayel, D. (2009). Performance of a modified precision vacuum seeder for no-till sowing of maize and soybean. Soil \& Tillage Research, 104, 121125.

Kertèsz, Á., \& Madarász, B. (2014). Conservation Agriculture in Europe. International Soil and Water Conservation Research, 2, 91-96.

Lal, R., Reicosky, D. C., \& Hanson, J. D.(2007). Evolution of the plow over 10,000 years and the rationale for no-till farming. Soil \& Tillage Researh, $93,1-12$.

Ogle, S. M., Swan, A., \& Paustian, K. (2012). No-till management impacts on crop productivity, carbon input and soil carbon sequestration. Agriculture, Ecosystems and Environment, 149, 37-49.

Paudel, B., Radovich, T. J. K., Chan-Halbrendt, C., Crow, S., Tamang, B.B., Halbrendt, J., \& Thapa, K. (2014). Effect of conservation agriculture on maize - based, farming system in the mid-hills of Nepal. Procedia Engineering, 78, 327-366.

Pittelkow, M. C., Linquist, A. B., Lundy, M. E., Liang, X., Groenigen, K. J., Lee, J., Gestel, N., Six, J., Venterea, R. T., \& Kessel, C. (2015). When does no-till yield more? A global meta-analysis. Field Crops Researh, 183, 156-168.

Schmitz, M., Mal, P., \& Hesse, J. W. (2015).The importance of conservation tillage as a contribution to sustainable agriculture. A special case of soil erosion, Agribusiness-Forschung, Nr. 33, Institutfür Agribusiness.

Soane, B. D., Ball, B. C., Arvidsson, J., Basch, G., Moreno, F., \&RogerEstrade, J. (2012). No-till in northern, western and south-western Europe: A review of problems and opportunities for crop production and the environment. Soil \& Tillage Research, 118, 66-87.

Jeftinïi krediti za poljoprivrednike - kamata 3 odsto (2010). Retrieved from http:// www.mpzzs.gov.rs/jeftiniji-krediti-za-poljoprivrednike-kamata-3odsto/

Soils are endangered, but the degradation can be rolled back (2015). Retrieved from http://www.fao.org/news/story/en/item/357059/icode/

The European Parliament tackles the benefits of Conservation agriculture in the seminar "Making Sustainable Agriculture Real" (2016). Retrieved from http:// www.ecaf.org/inaction/news/item/48-the-european-parliamenttackles-the-benefits-of-conservation-agriculture-in-the-seminar-making -sustaniable-agriculture-real

No-tillage (2015). Retrieved from http://www.rolf-derpsch.com/en/no-till/

What is conservation agriculture? (2015). Retrieved from http://www.ecaf.org/cain-europe/what-is-ca

\section{Ekonomska efektivnost primene direktne setve u proizvodnji kukuruza}

\section{Desanka Žuža · Todor Marković}

Sažetak: U sklopu koncepta održivog razvoja poljoprivrede, podizanja ekološke svesti poljoprivrednih proizvođača i očuvanja prirodnih resursa, tokom 60-ih godina XX veka u SAD-u je otpočela primena tzv. konzervacijske obrade zemljišta. Ovaj pojam obuhvata primenu redukovane ili sasvim eliminisane (direktna setva) predsetvene obrade zemljišta, koja sistemom tehničkih mera sprečava eroziju zemljišta, poboljšava kvalitet i biodiverzitet zemljišta uz značajno smanjenje emisije štetnih gasova. Primena ovog koncepta pretpostavlja postojanje adekvatne mehanizacije, koja omogućava primenu direktne setve na zemljištu na kom postoje biljni ostaci od prethodno uzgajane kulture u iznosu od minimum 30\%. Pored značajnog ekološkog uticaja, ovaj koncept omogućava pozitivne ekonomske efekte: za celokupno društvo kroz eliminisanje troška koji nosi sa sobom degradacija zemljišta, ali i za individualne poljoprivredne proizvođače kroz eliminisanje značajnog broja zahtevnih mašinskih operacija i ušteda u dizel gorivu i radnim časovima mašina i zaposlenih, koje proističu iz toga. Komparativnom analizom ekonomske efektivnosti proizvodnje kukuruza u uslovima konvencionalne i redukovane obrade, na jednom gazdinstvu sa teritorije grada Novog Sada, utvrđeno je da primena direktne setve omogućava preskakanje 4 do 5 mašinskih operacija, što vodi ka uštedi od 59 litara dizel goriva po ha uzgajane površine, uz zadržavanje istog nivoa prinosa, što je rezultovalo ostvarenjem većeg profita za 4.246 RSD ha- $^{-1}$ u odnosu na konvencionalnu obradu.

Ključne reči: direktna setva, ekonomika poljoprivrede, ekonomska analiza, isplativost, kukuruz, redukovana obrada 